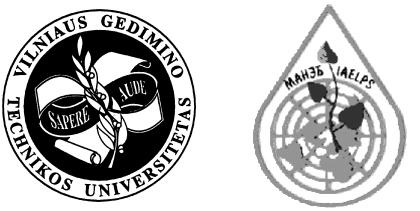

\title{
EQUIVALENT DOSE RATE OF IONIZING RADIATION ABOVE WATER RESERVOIRS IN VILNIUS
}

\author{
Milda Pečiulienė, Dainius Jasaitis, Gražina Grigaliūnaitė-Vonsevičienė, Aloyzas Girgždys
}

\author{
Laboratory of Nuclear Hydrophysics, Vilnius Gediminas Technical University, \\ Sauletekio al.11,LT-10223 Vilnius-40,Lithuania.E-mail: algi@fm.vtu.lt
}

Received 12 Feb 2004; accepted 1 Mar 2004

\begin{abstract}
The paper discusses search of possible pollution sources of natural radionuclides; the measuring method (using the GPS system) of the equivalent dose rate of the environment is introduced; the equivalent dose rate of water reservoirs of Vilnius is measured; the values and variations of equivalent dose rate are evaluated; it is found that the values cover the range from $10 \mathrm{nSv} / \mathrm{h}$ to $85 \mathrm{nSv} / \mathrm{h}$; it is noticed that the values measured above water are distinctly less than the equivalent dose rate above the soil surface; comparative analysis between the equivalent dose rate of open water reservoirs of Vilnius and other rivers and lakes of Lithuania is carried out.
\end{abstract}

Keywords: ionizing radiation, natural radionuclides, exposure, dosimetry, equivalent dose rate.

\section{Introduction}

Cosmic radiation and ionizing earth radiation, spread by radionuclides that are in the earth's crust, atmosphere and water, constantly affected life development. Over 60 natural radionuclides are found in the earth's crust, 32 of them belong to the most radioactive lines: uranium-radium, uranium-actinium and thorium [1].

The impact of internal and external natural exposure upon all human beings has not changed for thousands of years. An individual annually gets approximately the dose of $2 \mathrm{mSv}$ of internal and external exposure. Internal exposure doubles external exposure [1].

Radionuclides enter the human body through the respiratory system and biological nourishment chain and biological nourishment chain and become one of the exposure sources. Release radicals - the result of ionizing radiation - destroy the membrane of various cells or affect the cells themselves. Even small quantities of radionuclides can do harm to the human body, therefore, additional ionizing radiation must be reduced to a minimum.

Ionizing and cosmic radiation of radioactive substances, found in the air and on the surface of the earth, causes equivalent dose rate in the earth surface air [2]. Equivalent dose rate is the most important parameter because it most reflects the impact of ionizing radiation upon human being.
Constant control of additional sources of radioactive pollution is urgent; they must be monitored and their impact must registered. Unfortunately, nowadays we face the consequences of multi-year pollution. Lithuania's environment has been affected by nuclear explosions and the Chernobyl Nuclear Plant accident. Movement of radioactive substances from highly polluted regions of the Ukraine and Byelorussia is still in progress. Moreover, there is always potential danger of release of radioactive substances into the environment due to possible accidents at venues of nuclear industry.

The issue of radionuclide behavior in water has always been very important nowadays [3-5]. The feature of open water reservoirs to accumulate pollution should cause worry because water, especially in urban areas, is widely used for human consumption.

Aims and task of the search:

- to gather information about rivers, lakes, reservoirs and other water reservoirs of Vilnius for evaluating radiologic condition;

- to carry out search of possible pollution sources and territories polluted with radionuclides of an artificial origin;

- to estimate the dose of ionizing radiation exposure above water surface.

\section{Investigation methods}

The list of open water reservoirs intended for the 
investigation was composed according to the inventory file (1985) of Vilnius water reservoirs and state-of-art maps.

At that time 316 water reservoirs were found and registered in the city zone; this number does not include the water reservoirs of fenced territories of plants and institution gardens. This number includes the following: 30 lakes (a general area of $178 \mathrm{ha}$ ) and 286 ponds (a general area of $38 \mathrm{ha}$ ). There was no data about rivers and small rivers.

Due to fast development of Vilnius city, part of water reservoirs, especially the small ones, have undergone changes, for example, some reservoirs were destroyed, others joined to form bigger ones, the limits and depth of other ones have also changed, etc. Trying to fulfill the tasks and aims of the investigation the list found in the Inventory File of Vilnius City (1985) was supplemented and renewed due to various changes (for example, names of streets, etc). State-of-art maps and the newest data about the city were used.

Lakes, rivers and ponds of Vilnius city were studied to carry out search for possible sources of radionuclide pollution. Routes were chosen near the water side (for example, 3-5 $\mathrm{m}$ from the lake bank) for small water reservoirs and far and wide for the biggest ones.

Mobile equipment for measurement data registration and accumulation was created (Fig 1). It was installed in a boat or inflatable rubber boat. A boat is used for bigger water reservoirs, an inflatable rubber a boat for ponds and other smaller water reservoirs.

A radiometer detector registering particle impulses is fixed to the boat side and directed towards water surface. The distance between the detector and water is $30 \mathrm{~cm}$. A dateloger, connected to the radiometer, processes the data and sends it to a portable computer. The following data is accumulated in the portable computer: location co-ordinates, time and readings of the radiometer. Therefore, continuous measurement is carried out. In the case of equivalent dose rate increase a specific area was additionally studied at a lower rate.

The portable computer is connected to the Global Positioning System (GPS). The latter is a very precise radio navigation system providing information about the

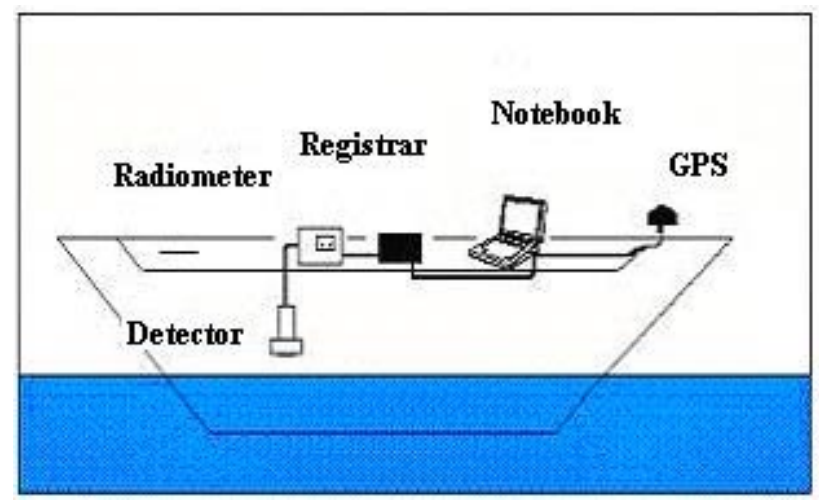

Fig 1. Scheme of measurements position of objects in space (3D), their velocity, direction and covered distance, the distance to selected points, exact time at a given moment and geographical sunrise/ sunset time and moon phases of a given location. GPS works in the same way in any place of the world independently of weather conditions, day time or season [6].

The data received from the registrar and GPS is accumulated in the computer. A computer of no lower class than Pentium is necessary for measurements.

Fig 2 presents automated equipment for radiometer measurements.

This instrument can measure equivalent dose rate above the water surface. It converts information into electrical signals and processes it further. Transference is carried out by a scintillate detector consisting of $\mathrm{NaJ}$ (T1) crystal and a photo-multiplier.

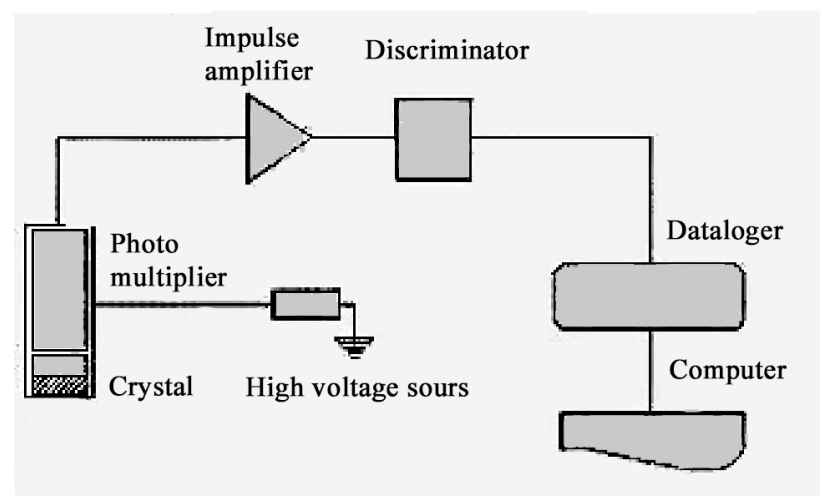

Fig 2. Scheme of automated equipment for radiometer measurements

\section{Measurement results}

According to the above described dosimetry measurement methods, investigation of dosimetry above open water reservoirs of Vilnius was performed.

Information about equivalent dose rate distribution in space was collected due to continuous data registration. The registration was especially important in search of pollution sources.

Fig 3 presents the measurement data of equivalent dose rate above open water reservoirs (above Antaviliai water reservoir). Each number corresponds to an average of measurement results in an investigated place.

The arithmetical average values of equivalent dose rate above water surface is presented in the Table. It is seen from the results that equivalent dose rate is higher above shallow water reservoirs. It is due to the influence of radionuclide radiation in the settling of the water reservoir ground. Radiation is reflected less by shallow water reservoirs.

Fig 4 presents the frequency of average equivalent dose rate. The values comprise a rather wide range: from $10 \mathrm{nSv} / \mathrm{h}$ to $85 \mathrm{nSv} / \mathrm{h}$. About $60 \mathrm{nSv} / \mathrm{h}$ is a mostly repeated value. Equivalent dose rate above water is lower than that above the earth's surface. The reason is that 
water absorbs some part of ionizing radiation. Water itself includes much less (100 and more times) radionuclides, therefore, equivalent dose rate above water for a depth of 3 and more meters is determined by cosmic radiation and air. The ionizing radiation of radionuclides in the air, water, ground and settlings determines the equivalent dose rate above the earth and water surface [7].

Detailed analysis of equivalent dose rate distribution above water reservoirs near Buivydiškès was carried out. The map of these reservoirs is shown in Fig 5 a; the data of this analysis is presented graphically in Fig 5 b. It is seen that towards the middle of a reservoir equivalent dose rate decreases. Equivalent dose rate above water close to the waterside is $30-70 \mathrm{nSv} / \mathrm{h}$, while in the middle it is $20 \mathrm{nSv} / \mathrm{h}$. The mentioned differences depend on many natural factors. Firstly, gamma radiation from the bottom decreases going deeper into a reservoir. Gamma radiation decreases ten times when the water layer reaches $0,5 \mathrm{~m}$, while at $1 \mathrm{~m}$ depth it remains less than $1 \%[8]$.

Secondly, shifting away from the waterside the in-

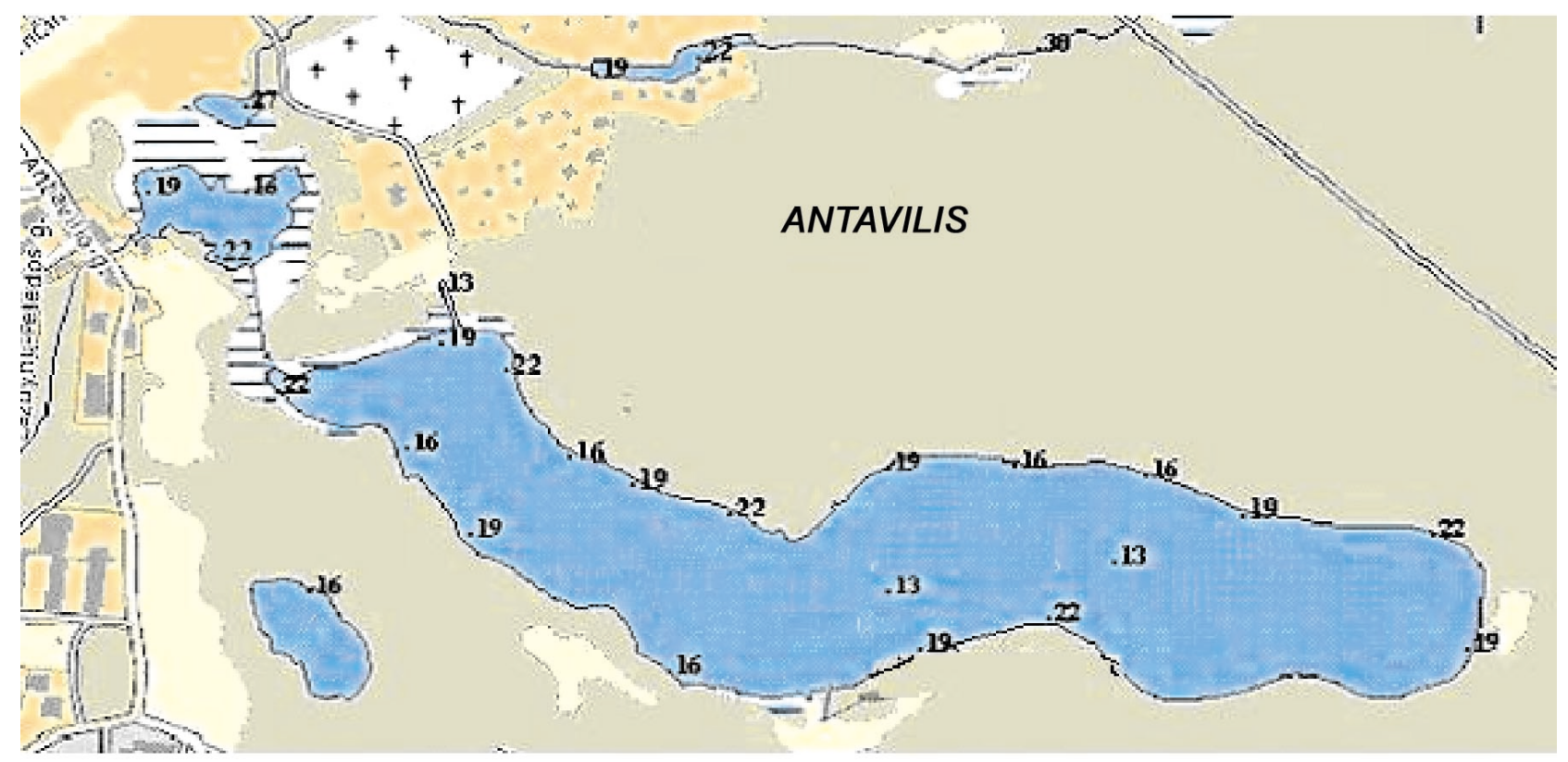

Fig 3. Water reservoirs in Antaviliai (each number corresponds to an average value of equivalent dose rate $[\mathrm{nSv} / \mathrm{h}]$ in an investigated place)

Average values of equivalent dose rate $[\mathrm{nSv} / \mathrm{h}]$ above water reservoirs in Vilnius

\begin{tabular}{|l|c|c|l|l|c|c|c|}
\hline \multicolumn{1}{|c|}{ Lake } & $\begin{array}{c}\text { Average } \\
\text { values of } \\
\text { equivalent } \\
\text { dose rate, } \\
\text { nSv/h }\end{array}$ & $\begin{array}{c}\text { Area, } \\
\text { ha }\end{array}$ & $\begin{array}{c}\text { Depth, } \\
\mathbf{m}\end{array}$ & \multicolumn{1}{c|}{$\begin{array}{c}\text { Ponds } \\
\text { (water reservoir address) }\end{array}$} & $\begin{array}{c}\text { Values of } \\
\text { equivalent } \\
\text { dose rate, } \\
\text { nSv/h }\end{array}$ & $\begin{array}{c}\text { Squere, } \\
\text { ha }\end{array}$ & $\begin{array}{c}\text { Depth, } \\
\text { m }\end{array}$ \\
\hline Gelūže & 17 & 17,5 & & near the Gulbinas lake & 66 & 0,013 & $-0,5$ \\
\hline Baltis & 19 & & & $\begin{array}{l}\text { near Popieriaus } \\
\text { street No 29 }\end{array}$ & 58 & 0,01 & $-0,5$ \\
\hline Salote & 20 & 9,8 & & Gulbinas street & 52 & 0,01 & -1 \\
\hline Buivydiškes & 32 & & & Kalvarijų street No 143 & 58 & 0,01 & -1 \\
\hline Balsys & 19 & 55,9 & & near the Balsys lake & 67 & 0,01 & $-0,5$ \\
\hline Gulbinas & 16 & 46,7 & & near the Gulbinas lake & 42 & 0,01 & -1 \\
\hline Antavilis & 17 & 16,6 & & Kairènai & 68 & 0,01 & -1 \\
\hline Balžis & 17 & & & Ozo street & 57 & 0,01 & $-1,5$ \\
\hline Tapeliai & 14 & 12,5 & -15 & Verkių street No 40 & 60 & 0,008 & -1 \\
\hline Juodis & 17 & 8,2 & $-3,5$ & Verkių street & 70 & 0,004 & -1 \\
\hline Skarbelelis & 16 & 2,25 & -10 & Dvarčionių street No 10 & 68 & 0,003 & $-0,6$ \\
\hline lake in Dvarčionys & 56 & 1,6 & -15 & Verkių street No 87 & 72 & 0,002 & $-0,5$ \\
\hline
\end{tabular}


fluence of the soil layer $(20-30 \mathrm{~cm})$ radiation decreases because the spatial corner decreases, i e gamma radiation depends on waterside geometry and radionuclide quantity. The third reason is short-existence products of radon split in the air and unequal distribution of their quantity above a water reservoir. The quantity of ${ }^{214} \mathrm{Bi}$, ${ }^{214} \mathrm{~Pb},{ }^{212} \mathrm{Bi}$ and ${ }^{212} \mathrm{~Pb}$ in the middle of a reservoir can be less than near the waterside in the case of weak wind or weak vertical air mixture.

According to the same methods (described in the methodological part) measurements of equivalent dose rate were carried out in other water reservoirs in Lithuania: Šventoji (near Ukmergè), the Vepriu and Rubikių lakes. An average equivalent dose rate above these water reservoirs reached, correspondingly: $63 \mathrm{nSv} /$ $\mathrm{h}, 56 \mathrm{nSv} / \mathrm{h}$ and $39 \mathrm{nSv} / \mathrm{h}$. These results correspond to the average equivalent dose rate found above open water reservoirs of Vilnius (Fig 4). To summarize, open water reservoirs of Vilnius are not exceptional in the sense of ionizing radiation.

It is known that Lithuanians get approximately from $250 \mathrm{nSv} / \mathrm{h}$ to $1140 \mathrm{nSv} / \mathrm{h}$ from natural sources. A trivial conclusion can be drawn: people being above water surface further from watersides get the least dose of ionizing radiation.

According to the data, some water reservoirs with a high equivalent dose rate because of anthropogenic activities cannot be distinguished.

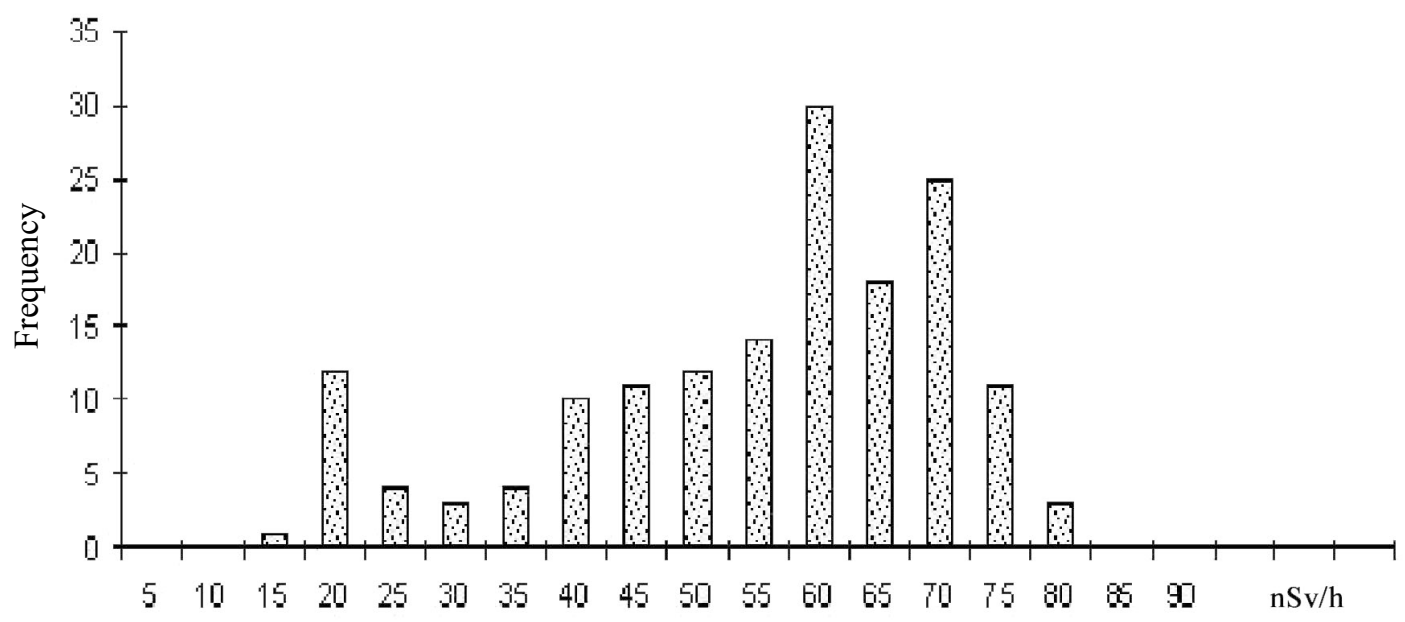

Fig 4. Frequency of average equivalent doze rate $[\mathrm{nSv} / \mathrm{h}]$ above water reservoirs in Vilnius
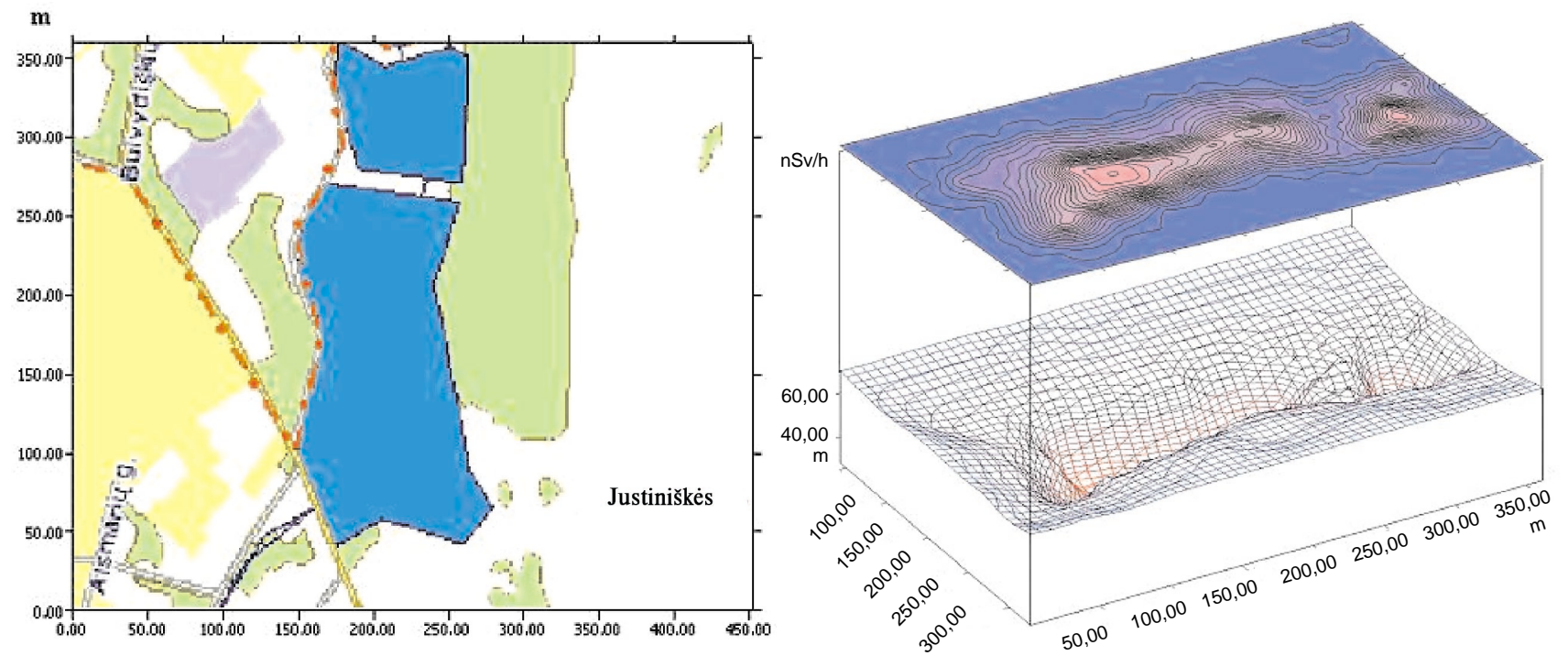

Fig 5. Water reservoirs investigated near Buivydiškès: a) a map; b) equivalent doze rate distribution above a water reservoir 


\section{Conclusions}

1. A method of measuring environmental equivalent dose rate is created. It enables to register continuously equivalent dose rate and measurement location coordinates using GPS (Global Positioning System).

2. Equivalent dose rate above water covers a range from $10 \mathrm{nSv} / \mathrm{h}$ to $85 \mathrm{nSv} / \mathrm{h}$. Approximately $60 \mathrm{nSv} / \mathrm{h}$ is a mostly repeated value. Equivalent dose rate values above shallower water reservoirs are higher due to cosmic radiation and ionizing radiation of radionuclides which are in the air, bottom ground and settlings.

3. Average equivalent dose rate values above soil highly exceed those above water.

4. Average equivalent dose rate above water reservoirs of Vilnius near the waterside reaches $30-70 \mathrm{nSv} /$ $\mathrm{h}$, in the middle of a water reservoir it is $20 \mathrm{nSv} / \mathrm{h}$. It can be stated that equivalent dose rate above water accounts for $10 \%$ of all natural radiation.

\section{References}

1. Nedveckaite, T. Radiation protection in Lithuania (Radiacinè apsauga Lietuvoje). Vilnius: Science and Encyclopaedia Publishing Institute, 1998, p 22-32 (in Lithuanian).

2. Lebedyte, M.; Butkus, D. Equivalent dose rate of ${ }^{222} \mathrm{Rn}$ splitting products gamma radiation in the air above ground surface. Environmental Engineering (Aplinkos inžinerija), Vol 9, No 3. Vilnius: Technika, 2001, p. 153-157 (in Lithuanian).

3. Robins, J. A.; Jasinski, A. W. Chernobyl fallout radionuclides in lake Sniardwy, Poland. Journal of Environmental Radioactivity, No 27, 1995, p 13-34.

4. Hakanson, L. A. Compilation of empirical data and variations in data concerning radiocesium in water, sediments and fish in European lakes after Chernobyl. Journal of Environmental Radioactivity, No 44, 1999, p 21-42.

5. Konoplev, A.; Kaminski, S.; Klemt, E.; Konopleva, I.; Miller, R.; Zibold, G. Comparative study of ${ }^{137} \mathrm{Cs}$ partitioning between solid and liquid phases in Lake Constance, Lugano and Vorsee. Journal of Environmental Radioactivity, No 58, 2002, p 1-11.

6. Global Positioning System: http://www.gpsworld.com/ gpsworld.

7. Konstantinova, M.; Butkus, D. Estimation of exterior equivalent dose rate caused by natural origin gamma radiation within the soil (Natūralios kilmès gama spinduliu, esančiu dirvoje, sukeltos išorinès lygiavertès dozės galios ivertinimas). Health Sciences, No 3. Vilnius, 2003, p 5054 (in Lithuanian).

8. Nuclear physics guide (Справочник по ядерной физике). Moscow, State edition of physics-mathematics works, 1963, p 130-162 (in Russian).

\section{JONIZUOJANČIOSIOS SPINDULIUOTĖS LYGIAVERTĖS DOZĖS GALIA VIRŠ VILNIAUS MIESTO VANDENS TELKINIŲ}

\author{
M. Pečiulienė, D. Jasaitis, G. Grigaliūnaitė-Vonsevičienė, \\ A. Girgždys
}

\section{Santrauka}

Straipsnis apie galimų taršos radionuklidais šaltinių paieškos būdus. Pateikiamas tam tikslui sukurtas mobilusis metodas (taikant GPS sistemą) jonizuojančiosios spinduliuotès lygiavertès dozès galiai aplinkoje išmatuoti. Nustatyta jonizuojančiosios spinduliuotès lygiavertès dozès galia virš Vilniaus teritorijoje esančiu vandens telkinių ir įvertinti jos pokyčiai. Nustatytas reikšmiu diapazonas - nuo $10 \mathrm{nSv} / \mathrm{h}$ iki $85 \mathrm{nSv} / \mathrm{h}$. Išmatavus pastebèta, $\mathrm{kad}$ virš vandens jonizuojančiosios spinduliuotès lygiavertès dozès galia daug mažesnè nei virš dirvos paviršiaus. Palyginta jonizuojančiosios spinduliuotès lygiavertès dozès galia virš Vilniaus miesto atvirų vandens telkinių ir kitų Lietuvos upių ir ežerų.

Raktažodžiai: jonizuojančioji spinduliuote, gamtinès kilmès radionuklidai, apšvita, dozimetrija, lygiavertès dozès galia.

\section{МОЩНОСТЬ ЭКВИВАЛЕНТНОЙ ДОЗЫ ИОНИЗИРУЮЩЕГО ИЗЛУЧЕНИЯ НАД ВОДОЕМАМИ ГОРОДА ВИЛЬНЮСА}

\section{М. Пячулене, Д. Ясайтис, Г. Григалюнайте- Вонсявичене, А. Гиргждис}

Резюме

Описываются способы поиска возможных источников загрязнений радионуклидами. Представлен созданный для этой цели мобильный метод (с использованием системы GPS) для измерения мощности эквивалентной дозы облучения в окружающей среде. Измерена мощность эквивалентной дозы облучения над водоемами, находящимися на территории города Вильнюса. Выяснены величины и изменения мощности эквивалентной дозы облучения. Установлено, что значения этих величин колеблются в пределах от 10 нЗв/ч до 85 н3в/ч. Замечено, что величины, измеренные над поверхностью воды, значительно меньше средней эквивалентной дозы облучения, измеренной над поверхностью почвы. Мощность эквивалентной дозы облучения водоемов города Вильнюса сравнена с фонами концентрации над реками и озерами Литвы.

Ключевые слова: ионизирующее излучение, естественные радионуклиды, облучение, дозиметрия, мощность эквивалентной дозы облучения. 